\title{
Ethological activities, ruminal parameters and weight gain of calves supplemented with different amounts of sodium chloride ${ }^{1}$
}

\author{
Pedro Malafaia ${ }^{2 *}$, Rosane Scatamburlo Lizieire ${ }^{3}$, Paula Barroso Cruz ${ }^{4}$ \\ and Paulo Vargas Peixoto ${ }^{2}$
}

\begin{abstract}
Malafaia P., Lizieire R.S., Cruz P.B. \& Peixoto P.V. 2012. Ethological activities, ruminal parameters and weight gain of calves supplemented with different amounts of sodium chloride. Pesquisa Veterinária Brasileira 32(8)803-806. Departamento de Nutrição Animal e Pastagem, Instituto de Zootecnia, Universidade Federal Rural do Rio de Janeiro, Seropédica, RJ 23890-00, Brazil. E-mail: malafaia_ufrrj@yahoo.com.br

The daily weight gain, behavioral activities (grazing, ruminating and water consumption) and the number of rumen protozoa, $\mathrm{pH}, \mathrm{NH}_{3}$ and the osmolarity of rumen fluid was evaluated for four groups of six calves HPB/Zebu submitted to daily intake of 15, 30, 60 and $90 \mathrm{~g}$ of $\mathrm{NaCl}$ during 135 days ( $9^{\text {th }}$ Jan. to $24^{\text {th }}$ May 2008).Throughout the experimental period the calves were in perfect health condition and did not show any signs suggestive of chronic sodium poisoning. There was no significant difference in average daily gain of the calves as the intake of $\mathrm{NaCl}$ increased. No significant behavioral changes were observed in the activities of grazing and rumination. However, there was a noticeable change in the frequency of water consumption in the calves that ingested $90 \mathrm{~g} / \mathrm{d}$ of $\mathrm{NaCl}$; they went more often to the trough and drank more water than the group that ingested only $15 \mathrm{~g}$ sodium chloride/d. The osmolarity of ruminal liquid was higher in the group of calves fed $90 \mathrm{~g}$ of $\mathrm{NaCl} / \mathrm{d}$. The $\mathrm{pH}, \mathrm{NH}_{3}$ concentration and number of rumen protozoa was within the normal range.
\end{abstract}

INDEX TERMS: Cattle behavior, dairy calves, ruminal parameters, sodium intake.

RESUMO-- [Atividades etológicas, variáveis ruminais e ganho de peso de bezerras suplementadas com quantidades crescentes de cloreto de sódio.] 0 desempenho ponderal, as atividades comportamentais (pastar, ruminar e beber água) e a estimativa do número de protozoários, $\mathrm{pH}, \mathrm{NH}_{3}$ e da osmolaridade do líquido ruminal foram avaliados em quatro grupos de 6 bezerras HPB/Zebú submetidas a ingestão diária de 15, 30, 60 e 90 gramas de $\mathrm{NaCl}$ por 135 dias (9 jan. a 24 mai. 2008). Por todo o período experimental, os animais estiveram em perfeita condição de saúde e não exibiram quaisquer sinais sugestivos da intoxicação crônica por sódio. Não houve diferença

\footnotetext{
${ }^{1}$ Received on March 8, 2012.

Accepted for publication on May 14, 2012.

${ }^{2}$ Departamento de Nutrição Animal e Pastagem, Instituto de Zootecnia (IZ), Universidade Federal Rural do Rio de Janeiro (UFRRJ), Seropédica, RJ 23890-000, Brazil. E-mail: pfpeixoto@terra.com.br*Corresponding author: malafaia_ufrrj@yahoo.com.br

${ }^{3}$ Pesagro-Rio, Estação Experimental de Seropédica, Antiga Estrada Rio-São Paulo, Km 47, Seropédica, RJ.

${ }^{4}$ Graduate student in Animal Science, UFRRJ, Seropédica, RJ.
}

significativa no ganho médio diário dos animais à medida que a ingestão de $\mathrm{NaCl}$ aumentou. Não foram detectadas alterações comportamentais significativas nas atividades de pastejo e ruminação. Entretanto, houve perceptível alteração na atividade de beber água e os animais que ingeriram $90 \mathrm{~g} / \mathrm{d}$ de $\mathrm{NaCl}$ aumentaram suas frequências de ida ao bebedouro e beberam mais água em relação ao grupo que ingeriu $15 \mathrm{~g} / \mathrm{d}$. A osmolaridade do líquido ruminal foi sempre maior no grupo de animais que consumiram $90 \mathrm{~g} / \mathrm{d}$ de $\mathrm{NaCl}$ e o $\mathrm{pH}$, a concentração de $\mathrm{NH}_{3}$ e número de protozoários também se situaram na faixa considerada normal.

TERMOS DE INDEXAÇÃO: Bovinos de leite, cloreto de sódio, comportamento animal, suplementação mineral.

\section{INTRODUCTION}

The proteic-energetic supplementation (PES), popularly known as "proteinados", is a nutritional strategy widely used for cattle production in Brazil and has the main objective to ensure maintenance or moderate weight gain in cattle during the dry season (Bisschoff et al. 1967, Pau- 
lino 1999, Malafaia et al. 2003). In 1961 arose the idea to control the daily intake of proteic-energetic supplements for cattle through the use of high levels of $\mathrm{NaCl}$ in the mixtures. The proposal, first developed in Brazil, was to avoid the daily work and reduce costs required for transport and distribution of these supplements in the feeders (Bisschoff et al. 1967).

In general, the proteic-energetic supplements have 20$35 \%$ of sodium chloride $(\mathrm{NaCl})$ in their composition and are ingested by the cattle in the range of $200-300 \mathrm{~g} / \mathrm{animal} /$ day during the 4 or 5 months of the dry season (Malafaia et al. 2003). When these quantities of commercial PES are consumed it is possible to estimate an intake of $\mathrm{NaCl}$ in the range of 40-105g/animal/day (Malafaia et al. 2004, 2005).

While the manual of NRC (2001) estimated a daily intake of $10-20 \mathrm{~g}$ of $\mathrm{NaCl}$ for cattle in the growth phase, Underwood \& Suttle (1997) and Tokarnia et al. (2010) suggest that adult cattle consume on average $30 \mathrm{~g} \mathrm{NaCl}$ per day. Therefore, the intake of higher quantities for prolonged periods, such as those found with use of proteic-energetic supplements, needs to be investigated from the standpoint of poisoning, or possible change in behavioral and physiological variables in the rumen.

In ruminants, sodium poisoning can be acute or chronic (Tokarnia et al. 2010), the latter occurs with excessive sodium intake for long periods and in situations of water restriction (NRC 2001, Tokarnia et al. 2010).

Thus, this study aimed to evaluate the clinical aspects, daily weight gain, ethological activities, daily water intake, rumen protozoa counts, and to measure $\mathrm{pH}$ and osmolality of the rumen fluid of crossbred HPB/Zebu calves supplemented with increased quantities of $\mathrm{NaCl}$ in their daily feeding.

\section{MATERIALS AND METHODS}

The experiment was conducted at the Experimental Station of Pesagro-Rio, Seropédica/RJ, Brazil, for 135 days, from $9^{\text {th }}$ January to $24^{\text {th }}$ May 2008. We used four groups of six calves HPB/Zebu, with initial weight of $148-152 \mathrm{~kg}$, properly vaccinated, identified and dewormed. All procedures were approved by the Committee of Ethics for the use of animals in research of UFRRJ.

Throughout the experimental period, all calves stayed together in the same area of Tanzania grass (Panicum maximum Jacq.) pasture managed in a rotational stocking system with 7 days of paddock occupation and 28 days of rest. Only at the time of feeding the calves were conducted to a restricted area and separated according to the experimental treatment proposed as follows:

Group1: $15 \mathrm{~g}$ of $\mathrm{NaCl} / \mathrm{d}$;

Group2: $30 \mathrm{~g}$ of $\mathrm{NaCl} / \mathrm{d}$;

Group3: $60 \mathrm{~g}$ of $\mathrm{NaCl} / \mathrm{d}$;

Group4: $90 \mathrm{~g}$ of $\mathrm{NaCl} / \mathrm{d}$.

To ensure that the calves consumed the respective amounts of sodium chloride, they received their daily quantities of $\mathrm{NaCl}$ mixed previously with $600 \mathrm{~g}$ of concentrate that contained $670 \mathrm{~g} /$ $\mathrm{kg}$ of ground corn and $330 \mathrm{~g} / \mathrm{kg}$ of soybean meal. The concentrate was provided in three portions (at 8, 13 and 17 hours) of $200 \mathrm{~g}$ per animal. This fractionation ensured that the amount of salt was completely ingested by the calves, and also simulated the habit of consumption of proteic-energetic supplements for cattle that frequently lick the product 3 to 6 times per day (Malafaia et al. 2003).
On February 17, March 15 and April 18, the calves of Group 1 $(15 \mathrm{~g} \mathrm{NaCl} / \mathrm{d})$ and Group $4(90 \mathrm{~g} \mathrm{NaCl} / \mathrm{d})$ were placed into a pasture of Brachiaria decumbens with about 0.8 ha divided by an electric fence. During these three days, the animals were monitored every 15 minutes for 24 consecutive hours, by different observers in the morning, the afternoon and evening. The ethological variables studied were the activities of grazing, ruminating and drinking water. Data were recorded on a spread sheet and interpreted in graphical form, as the percentage of animals performing an activity at any given time. The average daily water consumption was measured by a meter placed in the pipeline that supplied the drinking fountain for each paddock.

On March 21 and May 15, three calves of Group 1, and three of Group 4 were arrested for 8, 15 and 18 hours to be submitted to the collection of rumen fluid with an esophageal tube attached to a vacuum pump. Immediately after collection the rumen fluid was filtered through a triple layer of cheesecloth and subjected to reading of the $\mathrm{pH}$ and osmolarity by means of a portable potentiometer. An aliquot of $10 \mathrm{~mL}$ was frozen at $-20^{\circ} \mathrm{C}$ for future analysis of NH3. After thawing the sample, the concentration of $\mathrm{NH} 3$ in the ruminal fluid was determined by micro-Kjeldahl system without acid digestion of the sample $(2 \mathrm{ml}$ of ruminal fluid $+13 \mathrm{ml}$ distilled water) and using $\mathrm{KOH}(2 \mathrm{~N})$ in the distillation. After these procedures, a $5 \mathrm{~mL}$ sample was placed into a tube containing $5 \mathrm{~mL}$ of $30 \%$ formaldehyde. This sample was intended for the counting of rumen protozoa, which was performed with a Neubauer chamber.

The calves were weighed at the beginning of the experiment for formation of the groups and then at intervals of 28 days, always after solid and liquid fasting of 15 hours. The experiment was performed in a completely randomized design, and the values of the average daily weight gains were subjected to analysis of variance using the model $\mathrm{Yij}=m+T i+e i j$, where $\mathrm{Yij}$ is equal to the value observed in the $j$ th experimental unit, which received the $i t h$ treatment; $m$ means the overall average; Ti equals the treatment effect, and eij means the experimental error, assumed as normal and independently distributed with zero mean and variance $\sigma 2$. The Tukey test $(\alpha=5 \%)$ was chosen to discriminate the existence of differences between treatment means.

\section{RESULTS AND DISCUSSION}

Throughout the experimental period the calves were in perfect health condition, always gained weight (Table 1), grazed greedily and ate normally the concentrate containing different amounts of $\mathrm{NaCl}$. No calf showed clinical symptoms suggestive of chronic poisoning by sodium (diarrhea, lethargy, weakness, incoordination and anorexia).

Meyer et al. (1955) reported that the concentration of 9.33\% $\mathrm{NaCl}$ (about 3.7\% $\mathrm{Na}$ ) in dry matter (DM) intake did not cause deleterious effects, during 84 days, in weight gain

Table 1. Daily intake of $\mathrm{NaCl}(\mathrm{iNaCl})$, average of initial weight (AIW), final weight (AFW) and of daily weight gain (ADG) and standard error (SE)

\begin{tabular}{cccccc}
\hline $\begin{array}{c}\text { Experimental } \\
\text { group }\end{array}$ & $\begin{array}{c}\text { iNaCl } \\
\text { (g/day) }\end{array}$ & $\begin{array}{c}\text { AIW } \\
(\mathrm{kg})\end{array}$ & $\begin{array}{c}\text { AFW } \\
(\mathrm{kg})\end{array}$ & $\begin{array}{c}\mathrm{ADWG}^{*} \\
(\mathrm{~kg})\end{array}$ & $\mathrm{SE}$ \\
\hline 1 & 15 & 152.3 & 2055 & $0.506^{\mathrm{a}}$ & 0.147 \\
2 & 30 & 150.2 & 200.3 & $0.478^{\mathrm{a}}$ & 0.134 \\
3 & 60 & 151.2 & 202.8 & $0.492^{\mathrm{a}}$ & 0.081 \\
4 & 90 & 148,7 & 198,2 & $0,471^{\mathrm{a}}$ & 0,130
\end{tabular}

*Means, and in the same column followed by same letter do not differ at $5 \%$ by Tukey test. 

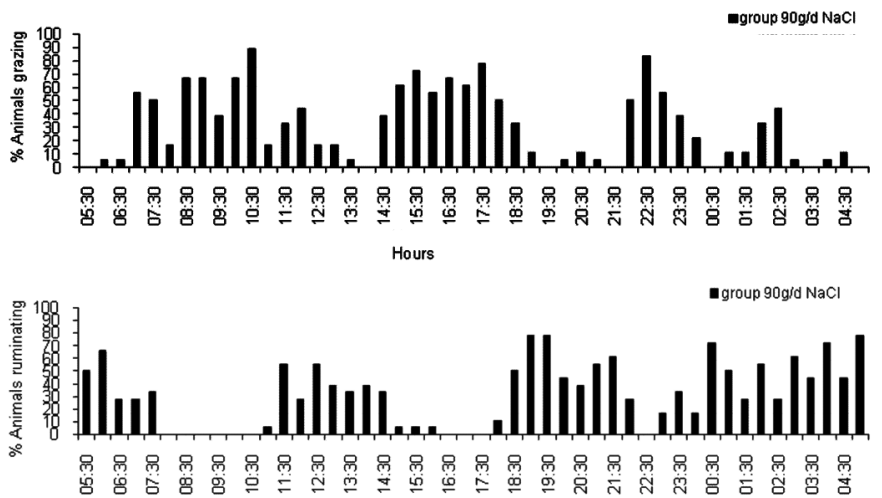
Hours

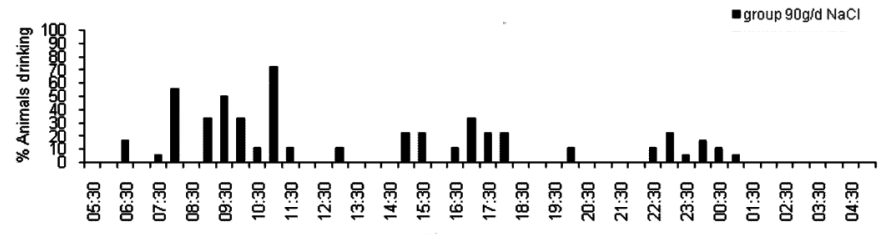
Hours

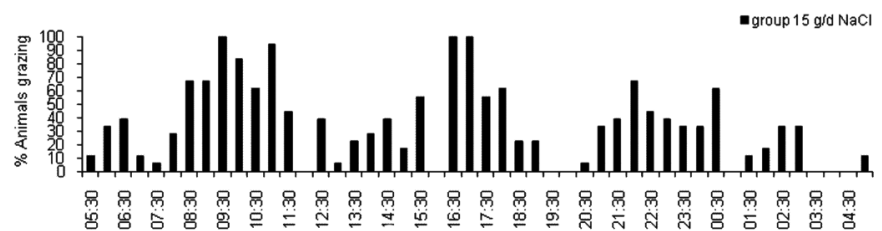

Hours

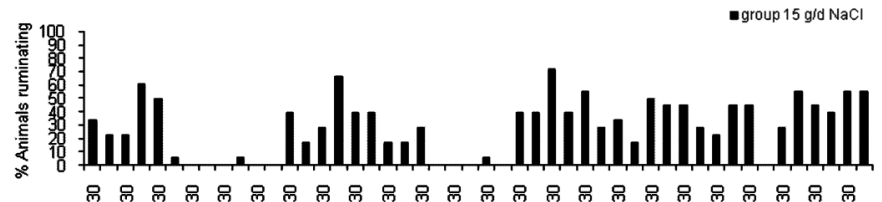

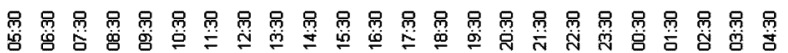
Hours

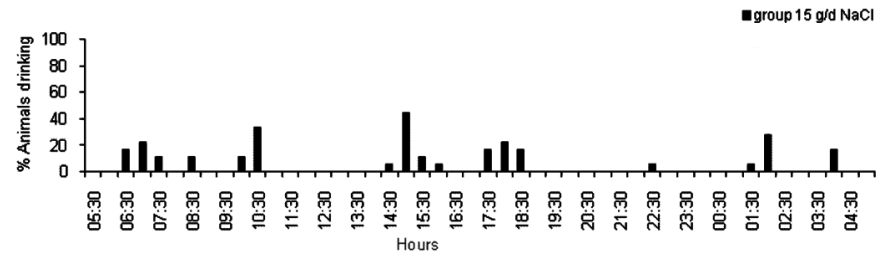

Fig.1. Ethological activities (grazing, ruminating and drinking water) of the calves that received 15 or $90 \mathrm{~g} / \mathrm{d}$ of $\mathrm{NaCl}$.

and nutrient utilization by cattle in the fattening stage. Moreover, the manual of NRC 2001, quoting a version of 1980 , recommends a maximum of $4 \% \mathrm{NaCl}(1.6 \% \mathrm{Na})$ in the $\mathrm{DM}$ consumed daily by lactating cows. Therefore, there is no reliable information on the maximum levels of $\mathrm{NaCl}$ to be tolerated by cattle during growth phase.

If the calves of the group which consumed as much sodium chloride $(90 \mathrm{~g} / \mathrm{d}$, with average weight of $173 \mathrm{~kg}$; Table 1), ingested $2.2 \%$ of $\mathrm{DM} /$ day in relation to their live weight, they would be able to consume 3800 grams of DM per day, what would be about $2.4 \% \mathrm{NaCl}$ in relation to their daily intake of DM.

The analysis of Table 1 shows that there was no significant difference in average daily weight gain of calves as the intake of $\mathrm{NaCl}$ increased. Although the consumption of 60 and $90 \mathrm{~g} / \mathrm{d}$ is considered high, even for adult cattle, these amounts have not reduced the daily weight gain during the experimental period.

In Figure 1 is possible to note that no significant behavioral changes were observed in the activities of grazing and rumination. However, as previously described by Carvalho Filho et al. 2003, there were noticeable changes in the activity of drinking water (Fig.1) and the animals that received $90 \mathrm{~g} / \mathrm{d}$ of $\mathrm{NaCl}$ increased their frequency to visit the trough and drank more water than the group that received only $15 \mathrm{~g} / \mathrm{d}$ of $\mathrm{NaCl}$ (Table 2). There was little variation between day and night in the daily water consumption (Table 2).

The Figure 2 shows that the rumen $\mathrm{pH}$ remained within the normal range (6.6 to 7.0) irrespectively of intake of the different amounts of $\mathrm{NaCl}$. The $\mathrm{pH}$ in this range is explained by the small amount of concentrate ingested daily $(600 \mathrm{~g} / \mathrm{d})$. Although within the normal range (240-360mMol/L (Owens \& Goetsch 1989), the osmolarity of the rumen fluid was higher in the group of calves that consumed $90 \mathrm{~g} / \mathrm{d}$ of $\mathrm{NaCl}$ (Fig.2). The values found for the number of rumen protozoa were also within normal range $\left(10^{5}-10^{6}\right)$.

The amounts of $\mathrm{NaCl}$ intake were not able to cause a dramatic change in the rumen variables studied. A possible lack of positive response in this study, when compared with the Carvalho Filho et al. (2003), is based on the fact that in that study cattle had free access to the supplement (licked 6-8 times /day); but in this study, the calves received three times the daily supplement. Thus, in the study of Carvalho Filho et al. (2003) the calves were able to ingest $135 \mathrm{~g} / \mathrm{d}$ $\mathrm{NaCl}$, but in the present study they ingested only $90 \mathrm{~g} / \mathrm{d}$ in the treatment with the highest $\mathrm{NaCl}$ amount.

\section{CONCLUSIONS}

It is possible to provide up to $90 \mathrm{~g} / \mathrm{d}$ of $\mathrm{NaCl}$ via proteic-energetic supplements for calves in the post-weaning period without prejudice to their weight development. The greater amount of $\mathrm{NaCl}$ added to the concentrate caused changes in the dynamics of going to the trough, as the daily intake of $90 \mathrm{~g}$ of NaCL caused a significant increase in daily water consumption.

Ingestion of up to $90 \mathrm{~g} / \mathrm{d}$ of $\mathrm{NaCl}$ for 135 days did not result in damage to the health of the calves or in drastic change in the number of rumen protozoa, ammonia concentration, osmolarity and rumen $\mathrm{pH}$.

Table 2. Average daily intake (ADI) of water for animals

\begin{tabular}{cccccccc}
\hline Experimental group & $17 / 2 / 08$ & $15 / 3 / 08$ & $18 / 4 / 08$ & ADI (L/d/Animal) & SE* & \% Drunk at day & \% Drunk at night \\
\hline $15 \mathrm{gNaCl} / \mathrm{d}$ & 18.8 & 16.7 & 19,2 & 18.2 & 2.4 & 80.1 \\
$90 \mathrm{gNaCl} / \mathrm{d}$ & 22.0 & 23.8 & 22.6 & 22.8 & 1.8 & 77.7 & 22.3 \\
\hline
\end{tabular}

*SE = standard error of average. 

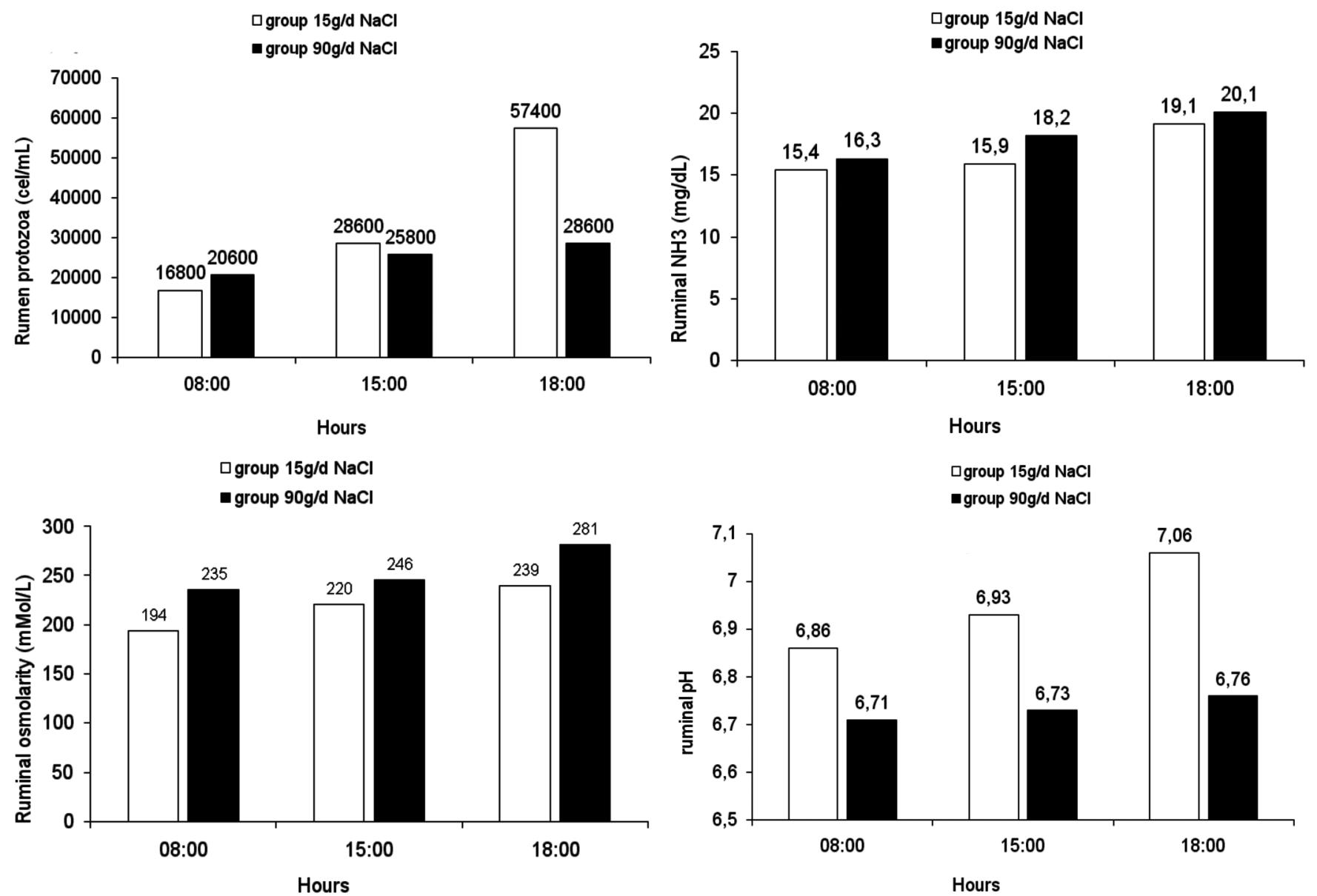

Fig.2. Rumen protozoa (cels/mL), $\mathrm{NH}_{3}(\mathrm{mg} / \mathrm{mL}$ ), osmolarity (mMom/L) and $\mathrm{pH}$.

\section{REFERENCES}

Bisschoff W.V.A., Quinn L.R., Mott G.O. \& Rocha G.L. 1967. Suplementações alimentares protéico-energéticas de novilhos em pastejo. Pesq. Agropec. Bras. 2:421-436.

Carvalho Filho M.T.P., Malafaia P. \& Vieira R.A.M. 2003. Consumo de nutrientes e desenvolvimento de novilhas leiteiras recebendo diferentes opções de suplementação concentrada. Revta Univ. Rural, Rio de J., 23(1):59-69.

Malafaia P., Cabral L.S., Vieira R.A.M., Magnoli Costa R. \& Carvalho C.A.B. 2003. Suplementação protéico-energética para bovinos criados em pastagens: aspectos teóricos e principais resultados publicados no Brasil. Livestock Research for Rural Development 15(12): Retrieved March 8, 112, from <http://www.lrrd.org/lrrd15/12/mala1512. htm>

Malafaia P., Lizieire R.S., Ronchi A.R., Valente T.N.P., Pereira D.L. \& Padilha T.F. 2004. Serragem de madeira como controlador da ingestão diária de um suplemento protéico-energético por novilhas durante a época seca. Livestock Research for Rural Development 16(3): Retrieved March 8, 112, from <http://www.lrrd.org/lrrd16/3/mal16015.htm>
Malafaia P., Lizieire R.S. \& Valente T.N.P. 2005. Suplementos protéicos-energéticos utilizados na recria de bezerras mestiças leiteiras. Anais $5^{\circ}$ Rio Sul Leite, Três Rios, p.125-128.

Meyer J.H., Weir W.C., Ittner N.R. \& Smith J.D. 1955. The influence of high sodium chloride intakes by fattening sheep and cattle. J. Anim. Sci. 14(2):412-418.

NRC - National Research Council 2001. Nutrient Requirements of Dairy Cattle. $7^{\text {th }}$ ed. National Academy Press, Washington, DC. 381p.

Owens F.N. \& Goetsch A.L. 1989. Ruminal fermentation, p.51-67. In: Church D.C. (Ed.), The Ruminant Animal: Digestive physiology and nutrition. Reston Book, New Jersey. 564p.

Paulino M.F. 1999. Estratégias de suplementação para bovinos de corte. Anais $1^{\circ}$ Simpósio de Produção de Gado de Corte, Viçosa, MG. Universidade Federal de Viçosa, Viçosa, p.137-156.

Tokarnia C.H., Peixoto P.V., Barbosa J.D., Brito M.F. \& Döbereiner J. 2000. Deficiências Minerais em Animais de Produção. Editora Helianthus, Rio de Janeiro. 191p.

Underwood E.J. \& Suttle N.F. 1997. The Mineral Nutrition of Livestock. CABI Publishing, London. 609p. 